\title{
Comparison of Lipid and Lipoprotein Values of Wrestlers and Soccer Players
}

\author{
Güreşçiler ve Futbolcuların Lipit ve Lipoprotein Değerlerinin \\ Karşılaştırılması
}

\author{
(D) Semra ÇETIN1, (D) Cuma ECE1, (D) Meltem PAKSOY1, (D) Hasan Nedim ÇETIN2* \\ 1Sakarya University of Applied Sciences, Faculty of Sports Science, Sakarya, Turkey \\ 2Lokman Hekim University, Faculty of Sports Science, Ankara, Turkey
}

\begin{abstract}
Objectives: The aim of this study was to compare the lipid and lipoprotein values of wrestlers and soccer players.

Materials and Methods: A total of 35 subjects, 17 male wrestlers who are sporting for 11.5 years and 18 male soccer player students who are sporting for 11.9 years, participated in this study. Triglyceride (TG), total cholesterol (TC), high-density lipoprotein cholesterol (HDL-C), and lowdensity lipoprotein cholesterol (LDL-C) levels were determined by Hitachi 717 autoanalyzer. To determine the differences between the wrestlers and the soccer players the independent t-test was performed.

Results: There was a significant difference in body weight and body mass index between the wrestlers and the soccer players ( $p<0.05$ ). Moreover, there were significant differences in plasma TC, LDL-C, and HDL-C values between the wrestlers and soccer players (all, $p<0.05$ ). However, there was no significant difference in plasma TG values between the wrestlers and the soccer players (p>0.05). On the other hand, TC and LDL-C values of the wrestlers were significantly higher than soccer players ( $p<0.05$ ). The HDL-C values of the soccer players were significantly higher the wrestlers ( $p<0.05)$. The ratio TC/HDL-C of the wrestlers was markedly higher than soccer players $(p<0.05)$.

Conclusion: TC, TG, HDL-C, and LDL-C values of the soccer players were in better ranges than wrestlers. This situation can be caused by the effect of different sports branches as well as the training differences. The lipid and lipoprotein values of the wrestlers and soccer players showed that they do not carry a risk of cardiovascular disease. In addition, it can be recommended that wrestlers should do jogging or aerobic training in their daily regular training.
\end{abstract}

Key words: Wrestler, soccer players, exercise, blood

ÖZ

Amaç: Bu çalıșmanın amacı güreșçilerin ve futbolcuların lipit ve lipoprotein değerlerinin karșılaștırılmasıdır.

Gereç ve Yöntemler: Bu çalışmaya 11,5 yıl spor yapan 17 erkek güreșçi ve 11,9 yıl spor yapan 18 erkek futbolcu öğrenci olmak üzere toplam 35 kiși katılmıştır. Trigliserit (TG), total kolesterol (TC), yüksek dansiteli lipoprotein kolesterol (HDL-C) ve düşük dansiteli lipoprotein kolesterol (LDL-C) düzeyleri Hitachi 717 otoanalizörü ile belirlenmiştir. Güreşçi ve futbolcu arasındaki farkları belirlemek için "bağımsız t" testi yapılmıştır.

Bulgular: Güreșçiler ile futbolcular arasında vücut ağırlığı ve vücut kitle indeksinde anlamlı fark bulunmuștur ( $p<0,05)$. Ayrıca, güreșçiler ve futbolcular arasında plazma TC, LDL-C ve HDL-C değerlerinde anlamlı farklılılar tespit edilmiştir (tümü, p<0,05). Bununla birlikte, güreșçiler ve futbolcular arasında plazma TG değerlerinde anlamlı bir fark bulunmamıştır ( $p>0,05)$. Güreşçilerin TC ve LDL-C değerleri futbolculara göre anlamlı derecede yüksektir ( $p<0,05)$. Futbolcuların ise HDL-C değerleri güreşçilerden anlamlı derecede yüksek bulunmuştur ( $p<0,05)$. Güreşçilerin TC/ HDL-C oranının futbolculara göre daha yüksektir $(p<0,05)$.

Sonuç: Futbolcuların TC, TG, HDL-C ve LDL-C değerleri güreş̧̧ilerle karşılaştırıldığında, daha iyi sınırlar içerisinde bulunmuştur. Bu duruma spor branşındaki ve antrenmandaki farklılıklar neden olabilir. Güreșçilerin ve futbolcuların lipit ve lipoprotein değerleri, kardiyovasküler hastalık tehlikesi taşımadıklarını göstermiştir. Bununla birlikte güreşçilerin günlük düzenli antrenmanlarında koşuya veya aerobik antrenmana daha fazla yer vermeleri tavsiye edilebilir.

Anahtar kelimeler: Güreşçi, futbolcular, egzersiz, kan

*Correspondence: E-mail: nedimcetin46@yahoo.com, Phone: +90 5322120741 ORCID-ID: orcid.org/0000-0002-5821-6563

Received: 21.11.2018, Accepted: 31.12.2018

๑Turk J Pharm Sci, Published by Galenos Publishing House. 


\section{INTRODUCTION}

Physically inactive lifestyle and low levels of cardiorespiratory fitness lead to an increase in the risk of developing numerous chronic diseases as well as all-cause mortality. In the middleaged and older periods health problems occur more commonly such as high blood pressure, obesity, muscular weakness, postural disorders, diabetes, and risk factors for coronary artery disease. Studies have shown that increasing risk factors for coronary heart disease (CHD) are high cholesterol, triglycerides (TGs), and low-density lipoprotein cholesterol (LDL-C) levels and low high-density lipoprotein cholesterol (HDL-C) levels in blood lipids. ${ }^{2}$ Both aerobic and anaerobic exercises can decrease total cholesterol (TC), raise HDL-C levels, and lower the TC/HDL-C ratio. The effect of exercise on LDL-C generally has been inconsistent and is regarded to be minor in magnitude. Among elite athletes, exercise continues to promote favorable lipoprotein profiles. Elevation in body mass index (BMI) has been associated with less favorable lipoprotein profiles, with an increased relative risk of $\mathrm{CHD}$, as well as increased mortality due to cardiovascular diseases. ${ }^{3}$ Studies support a significant incremental effect of exercise on blood lipids and lipoproteins in men. It has been reported that changes in $\mathrm{HDL}-\mathrm{C}$ levels with exercise training were inversely related to baseline HDL-C levels. These findings suggested that individuals with the lowest HDL-C levels would exhibit the greatest increases in HDL-C with exercise. ${ }^{4}$ The effects of physical activity on lipid and lipoprotein metabolism, TC, LDL-C, $\mathrm{TG}$, and TC/HDL-C ratio significantly decreased after exercises. Therefore, in order to become fit and to keep healthy, activities such as fitness, aerobics, and jogging are important. ${ }^{5}$

There is substantial, consistent, and strong evidence that physical activity is a deterrent for developing many forms of cardiovascular disease (CVD). Many studies have shown that the cholesterol is related to CHD. LDL-/HDL-C ratio can show an increased rate of arteriosclerosis. Low blood levels of HDL-C are an independent risk factor for CVD. ${ }^{6,7}$ Positive effects of applied long regular exercises on physical, physiological, psychological, and motoric features have been reported and one of the most important positive effects of regular exercise is on blood biochemistry. Regular and well-tuned intensity aerobic exercise reduces TC, LDL-C, TGs, and blood lipid levels, while increases HDL-C levels when estimated. ${ }^{8}$ Wrestling and soccer involve very vigorous physical activity. It has also been pointed out that hypercholesterolemia and low levels of HDL-C were more pronounced in power sports (i.e. weight lifting, boxing, wrestling, and judo) and anaerobic sports (i.e. tennis, sprints and jumps, gymnastics, and ice skating). 9.10 Physical activity has a beneficial effect on the serum lipid profile. The recognition of the cardiovascular risk in a sedentary lifestyle and of the benefits of regular exercise has led to the promotion of sport as a means to improve health and prevent certain diseases. However, the response of the lipid profile to an exercise session or training program is different depending on the type of exercise undertaken, its intensity and frequency, the duration of each session, and the time spent in such a program." A large number of epidemiological studies have revealed a relationship between dyslipidemia and the prevalence of atherosclerosis and CHD. Increased physical activity is associated with a reduction in the risk of CVD, but there is conflicting information about the optimal intensity and the amount of exercise necessary for this reduction. ${ }^{12}$ Epidemiological studies suggest that individually measured and programmed physical activity and the implementation of primarily aerobic physical activity lead to increased concentrations of HDL-C and lowered TG, TC, and LDL-C. When the intensity of the workout is well controlled, the power consumption is a major factor affecting lipids and lipoproteins. Training leads to a series of adaptation, morphological, and functional changes at the level of the cardiovascular system and neuromuscular system, as well as lipids. Recent studies have shown that dosed individually and programmed physical activity leads to increases in the concentration of HDL-C, and decreasing TG, TC, and LDL-C. ${ }^{13}$

The aim of the present study was to compare lipid and lipoprotein values of wrestlers and soccer players and to investigate CVD risks. It is thought that there is a difference between the lipid and lipoprotein values of soccer players and wrestlers because they have differences in terms of branches and training. Soccer players do aerobic training in their regular training more than wrestlers do. This study is important in terms of comparing lipid and lipoprotein values of wrestlers and soccer players.

\section{MATERIALS AND METHODS}

\section{Subjects}

Seventeen male wrestlers who had done sports for 11.5 years and 18 male soccer players who had done sports for at least 11.9 years, a total of 35 subjects, participated in the present study. The wrestlers were university students and national athletes. The soccer players were college students playing in different leagues. Written consent was obtained from all the participants, who volunteered to participate in the present study.

\section{Lipid and lipoprotein measurement}

Blood samples were obtained from the antecubital vein of the subjects $48 \mathrm{~h}$ before exercise sessions. Fasting blood samples were taken in the morning. The samples were analyzed for TG, TC, HDL-C, and LDL-C. These levels were determined by Hitachi 717 autoanalyzer. Blood samples were taken within the scope of the ethic committee report of Ondokuz Mayıs University (report no: B.30.2.ODM.0.20.08/255).

BMI =Body weight $(\mathrm{kg}) /$ Height $(\mathrm{m})^{2}=\left(\mathrm{kg} / \mathrm{m}^{2}\right)$

\section{Statistical analysis}

The analysis was performed using SPSS version 22. The Kolmogorov-Smirnov test was used to evaluate the normality of parameters. Comparisons of age and height were used and to determine the differences between the groups independent t-tests were performed. Statistical significance was set at $p<0.05$.

\section{RESULTS}

The physical anthropometric and motoric characteristics of the wrestlers and soccer players are given in Table 1. The 
serum lipid values are compared in Table 2. Table 3 shows the cardiovascular risk status of the participants.

\section{DISCUSSION}

Previous epidemiologic studies have demonstrated an increased risk of $\mathrm{CHD}$ and cardiovascular death with an increase in $\mathrm{BMI}{ }^{3}$ Stevens et al..$^{14}$ found among healthy men that increasing BMI was associated with an increased relative risk of cardiovascular death, particularly among younger subjects. The Canadian Heart Health Surveys Research group reported an increased prevalence of dyslipidemia associated with an elevated BMI; a positive association between BMI and TC, LDL-C, and TG levels; and an inverse relationship with HDLC levels. ${ }^{15}$ In another study, Garry and McShane ${ }^{3}$ found comparing mean lipid values among

Table 1. Physical characteristics of the wrestlers and soccer players

\begin{tabular}{llll} 
Parameters & Wrestlers & Soccer players & $\mathrm{t}$ \\
\hline Age (year) & $23.72 \pm 1.87$ & $24.10 \pm 1.75$ & 0.07 \\
\hline Body height $(\mathrm{cm})$ & $174.43 \pm 6.72$ & $174.16 \pm 6.81$ & 0.10 \\
\hline Body height $(\mathrm{kg})$ & $75.80 \pm 11.3$ & $69.49 \pm 9.6$ & $2.96^{*}$ \\
\hline BMl $\left(\mathrm{kg} / \mathrm{m}^{2}\right)$ & $25.04 \pm 3.64$ & $22.95 \pm 3.62$ & $2.88^{*}$ \\
\hline Years of training & $11.5 \pm 5.4$ & $11.9 \pm 5.5$ & 0.29
\end{tabular}

${ }^{*} \mathrm{p}<0.05, \mathrm{BMI}:$ Body mass index

Table 2. Comparison of serum lipid values of the wrestlers and soccer players

\begin{tabular}{|c|c|c|c|c|}
\hline $\mathrm{mg} / 100 \mathrm{cc}$ & Groups & Mean & SD & $t$ \\
\hline \multirow[t]{2}{*}{ TC } & Wrestlers & 177.69 & 12.34 & \multirow[t]{2}{*}{$3.67^{* *}$} \\
\hline & Soccer players & 163.34 & 12.60 & \\
\hline \multirow[t]{2}{*}{ TG } & Wrestlers & 96.65 & 14.95 & \multirow[t]{2}{*}{0.92} \\
\hline & Soccer players & 94.25 & 12.14 & \\
\hline \multirow[t]{2}{*}{ HDL-C } & Wrestlers & 54.72 & 3.82 & \multirow[t]{2}{*}{$2.16^{*}$} \\
\hline & Soccer players & 57.45 & 3.39 & \\
\hline \multirow[t]{2}{*}{ LDL-C } & Wrestlers & 132.63 & 15.43 & \multirow[t]{2}{*}{$2.68^{*}$} \\
\hline & Soccer players & 119.47 & 15.33 & \\
\hline
\end{tabular}

${ }^{*} p<0.05,{ }^{* *} p<0.001$, SD: Standard deviation, TC: Total cholesterol, TG: Triglyceride, HDL-C: High-density lipoprotein cholesterol, LDL-C: L-density lipoprotein cholesterol

Table 3. Risk of cardiovascular diseases of the wrestler and soccer players

\begin{tabular}{lllll}
\multirow{2}{*}{$\mathrm{mg} / 100 \mathrm{cc}$} & Groups & Mean & $\mathrm{SD}$ & $\mathrm{t}$ \\
\hline \multirow{2}{*}{ TC/HDL-C } & Wrestlers & 3.25 & 0.34 & \multirow{2}{*}{$2.28^{*}$} \\
\cline { 2 - 4 } & Soccer players & 2.84 & 0.35 & \\
\hline \multirow{2}{*}{ LDL-C/HDL-C } & Wrestlers & 2.42 & 0.27 & \multirow{2}{*}{1.16} \\
\cline { 2 - 4 } & Soccer players & 2.08 & 0.30 & \\
\cline { 3 - 4 } & &
\end{tabular}

${ }^{*} p<0.05$, SD: Standard deviation, TC: Total cholesterol, HDL-C: High-density lipoprotein cholesterol, LDL-C: L-density lipoprotein cholesterol
BMI categories demonstrated lower HDL-C ( $p<0.01$ ), higher TGs ( $p<0.05$ ), and higher TC/HDL-C ratios ( $p<0.001)$ with an increasing BMl in soccer players. In the present study, BMI for the wrestlers was higher than that for the soccer players. BMI was $25.14 \mathrm{~kg} / \mathrm{m}^{2}$ for the wrestlers and $22.95 \mathrm{~kg} / \mathrm{m}^{2}$ for the soccer players. There was a significant difference in body weight and BMI between the wrestlers and the soccer players ( $p<0.05)$. There was no significant difference between them in terms of age, body height, or years of training ( $p>0.05)$. The majority of studies showed that decreased TG, cholesterol, and LDL-C levels and increased HDL were the result of applied training when the severity, duration, and frequency of exercise were approved. ${ }^{16}$ A study involving soccer training found decreases in LDL, cholesterol, and LDH levels and a statistically significant result was found. ${ }^{17}$ The most important effect of exercise on the human body is on the metabolic system, especially lipids. Lipids and lipoproteins are risk factors for CHD. ${ }^{3}$ Most crosssectional studies indicate smaller, nonsignificant differences in TC and LDL-C levels between exercise-trained and sedentary individuals. ${ }^{18,19}$ Aydoğan ${ }^{16}$ found TG and HDL-C levels did not differ between wrestling groups. Imamoglu et al. ${ }^{4}$ stated that there were no significant differences in plasma TC and TG values between their groups of wrestlers and students. No significant differences were found in HDL-C and LDL-C values between wrestlers and male students. In the present study, there were significant differences in plasma TC, LDL-C, and HDL-C values between the wrestlers and the soccer players ( $p<0.05, p<0.001)$. There were no significant differences in plasma TG values between the wrestlers and the soccer players ( $p>0.05$ ). TC and LDL-C values of the wrestlers were significantly higher than those of the soccer players $(p<0.05)$. HDL-C values of the soccer players were significantly higher than those of the wrestlers $(p<0.05)$.

$\mathrm{Koc}^{8}$ found significant reductions in exercise-induced TC, cholesterol, and LDL-C and increases in HDL levels. Labović et al. $^{13}$ reported that athletes had lower TC, LDL-C, and TG levels and higher serum HDL than nonathletes. Friedmann and Kindermann ${ }^{19}$ found $\mathrm{HDL}-\mathrm{C}$ levels higher in an endurance training male group than in an inactive group. A lot of studies report that aerobic exercises increase HDL-C levels. Exercise is a potential factor that may modify lipid profiles and therefore reduce the risk for $\mathrm{CHD} .{ }^{20}$ Imamoglu et al. ${ }^{4}$ did not find $\mathrm{HDL}-\mathrm{C}$ to be significantly different between their groups. Because male wrestlers perform mostly nonaerobic exercises and strength training, exercises like these did not increase the HDL-C levels. At the end of their study, which investigated the effects of aerobic exercise on blood lipids, it was found that the exercise had no effect on TG or cholesterol parameters, but caused an increase in HDL-C level and a reduction in LDL-C level. ${ }^{21}$ In a previous study examining the effect of 6 weeks of wrestling and wrestling-technique-based circuit exercise on the plasma lipoprotein profile, it was shown that cholesterol and HDL decreased significantly. ${ }^{22}$ Some research reports a lower HDL-C in power-anaerobic athletes. ${ }^{4,23}$ When the literature was reviewed about the effects of exercise on plasma lipids and lipoproteins, the results indicated that moderate and low 
intensity exercises are of great importance. These events show an increase in HDL-C, decrease in LDL-C, and increased protective effects against arteriosclerosis. ${ }^{4}$ It has been identified that regular aerobic exercise reduces total blood cholesterol, serum TGs, and LDL-C and increases HDL-C. ${ }^{23,24}$ In the present study, the soccer players were found to have better HDL-C levels than the wrestlers. This may be the result of intensive training and nutrition. It is suggested that wrestlers should do more running and aerobic training.

People who have HDL-C cholesterol levels under 40 mg/100 cc have more than three times the risk of cardiovascular diseases than people who have high HDL-C levels. ${ }^{18}$ The periodic risk of heart disease can be estimated by dividing TC by HDL-C. As a result of the estimation 4.5-5 levels show important CVD risk, while 3.8-4 levels show low CVD risk. ${ }^{25}$ Another study reported that the risk factor is high if the TC/HDL-C ratio is higher than 5 and low if the ratio is lower than $3.5 .{ }^{24}$ Imamoglu et al. ${ }^{4}$ mentioned that the lipid and lipoprotein values of their four groups indicated that individuals in the exercise groups would not be exposed to the danger of cardiovascular diseases. The cardiovascular risk ratio of wrestlers is higher than that of other groups. Athletes engaging in aerobic sports at a high level are particularly favored with respect to their low overall risk of CHD and, in particular, to their highly favorable plasma lipoprotein pattern. ${ }^{26}$ High-intensity aerobic training results in improvement in HDL-C. ${ }^{2,27}$ Studies of large populations of men have shown that those who exercise at a moderate or strenuous level have a lower incidence of CHD. The effect of exercise has been shown in controlled studies to raise HDL-C levels, lower $\mathrm{TG}$, and lower the TC/HDL-C ratio. ${ }^{3}$ A training program that emphasizes strength, power, speed ability, resistance, explosive movements, and interval sprints can result in undesirable health and fitness consequences for the participants in poweranaerobic based sports. ${ }^{22}$ Garry and McShane ${ }^{3}$ demonstrated that the strongest relationship between $\mathrm{BMI}$ and lipoprotein levels occurred between $\mathrm{BMI}$ and the TC/HDL-C ratio. Wrestling is categorized as a power-anaerobic based sport on the basis of its nature of practice and competition times. ${ }^{22}$ In the present study the cardiovascular risk ratio (TC/HDL-C) was $3.25 \mathrm{mg} / 100$ $\mathrm{cc}$ for the wrestlers and $2.84 \mathrm{mg} / 100 \mathrm{cc}$ for the soccer players. The LDL-C/HDL-C was $2.42 \mathrm{mg} / 100 \mathrm{cc}$ for the wrestlers and $2.08 \mathrm{mg} / 100 \mathrm{cc}$ for the soccer players. In the present study, it is meaningful that the TC/HDL-C ratio of the wrestlers was higher than that of the soccer players $(p<0.05)$. There was no significant difference in the LDL-C/HDL-C ratio between the wrestlers and the soccer players ( $p>0.05$ ). The TC/HDL-C and LDL-C/HDL-C ratios for the wrestlers were higher than those for the soccer players. This can be attributed to the fact that the training form of the wrestlers is more anaerobic than that of the soccer players. Wrestlers and soccer player with the highest BMls and elevated TC/HDL-C ratios may be those at greatest risk for future CVD, regardless of their TC or LDL-C values.

\section{CONCLUSION}

The TC, TG, HDL-C, and LDL-C of the soccer players were better than those of the wrestlers. This situation can be caused by branches and training differences. This result shows that between wrestlers and soccer players there were differences in lipid and lipoprotein levels. The lipid and lipoprotein values of the wrestlers and soccer players showed that they are not at risk of cardiovascular disease. In addition, it is recommended that wrestlers should do jogging or aerobic training in their daily regular training.

Conflicts of interest: No conflict of interest was declared by the authors. The authors alone are responsible for the content and writing of the paper.

\section{REFERENCES}

1. Blair SN, Haskell WL. Objectively measured physical activity and mortality in older adults. JAMA. 2006;296:216-218.

2. Demirel N, Özbay S, Kaya F. The effects of aerobic and anaerobic training programs applied to elite wrestlers on body mass index (BMI) and blood lipids. J Educ Train Stud. 2018;6:58-62.

3. Garry JP, McShane JJ. Analysis of lipoproteins and body mass index in professional football players. Prev Cardiol. 2001;4:103-105.

4. Imamoglu O, Atan T, Kishali NF, Burmaoglu G, Akyol P, Yıldırım K. Comparison of lipid and lipoprotein values in men and women differing in training status. Biol Sport. 2005;22:261-270.

5. Lollgen $H$, Lollgen $D$. Risk reduction in cardiovascular diseases by physical activity. Internist (Berl). 2012;53:20-29.

6. Boden WE. High-density lipoprotein cholesterol as an independent risk factor in cardiovascular disease: assessing the data from Framingham to the Veterans Affairs High-Density Lipoprotein Intervention Trial. Am J Cardiol. 2000;86:19L-22L.

7. Franceschini G. Epidemiologic evidence for high-density lipoprotein cholesterol as a risk factor for coronary artery disease. Am J Cardiol. 2001;88:9N-13N.

8. Koc H. The comparison of blood lipid levels of athletes and sedentary college students. Pak J Med Sci. 2011;27:622-625.

9. McMurray R, Proctor P, Wilson WL. Effect of caloric deficit and dietary manipulation on aerobic and anaerobic exercise. Int J Sports Med. 1991;12:167-172.

10. Williams MH. Exercise effects on children's health. Sports Sci Exchange 4: (Gatorade Sport Sci. Inst. series), 1993:98.

11. Boraita A. Plasma lipid profile is improved by participation in sports, but at what intensivity? Rev Esp Cardiol. 2004;57:495-498.

12. Kraus WE, Houmard JA, Duscha BD, Knetzger KJ, Wharton MB, McCartney JS, Bales CW, Henes S, Samsa GP, Otvos JD, Kulkarni KR, Slentz CA. Effects of the amount and intensity of exercise on plasma lipoproteins. N Engl J Med. 2002;347:1483-1489.

13. Labović SB, Đonović N, Andrejević V, Banjari I, Kurgaš H, Zejnilović M. Lipid status of professional athletes. MD-Medical Data. 2015;7:21-25.

14. Stevens J, Cai J, Pamuk ER, Williamson DF, Thun MJ, Wood JL. The effect of age on the association between body mass index and mortality. N Engl J Med. 1998;338:1-7.

15. Rabkin SW, Chen Y, Leiter L, Liu L, Reeder BA. Risk factor correlates of body mass index. Canadian Heart Health Surveys Research Group. CMAJ. 1997:157:S26-S31. 
16. Aydoğan A. Comparison of lipid and lipoprotein values of different wrestlers. Eur J Sport Sci. 2017;3:39-46.

17. Selçuk M, Aslan TV, Temur HB, Çınar V. The healing effect of football trainings on lipid profile and muscle damage markers in 11-13 years old boys. Journal of Sports and Performance Researches. 2018;9:44-49.

18. Wood PD, Stefanick ML, Dreon DM, Frey-Hewitt B, Garay SC, Williams PT, Ellsworth NM. Changes in plasma lipids and lipoproteins in overweight men during weight loss through dieting as compared with exercise. N Engl J Med. 1988;319:1173-1179.

19. Friedmann B, Kindermann W. Vergleichende Untersuchungen zu Veränderungen der Lipoproteine und Apolipoproteine bei Frauen und Männern unterschiedlichen Trainings zustandes. In SportmedizinKursbestimmung. 1987;437-441.

20. Apostolidis N, Bogdanis GC, Kostopoulos N, Souglis A, Papadopoulos Ch. Changes in the lipid profile of elite basketball and soccer players after a match. Res Sports Med. 2014;22:100-110.

21. Leon AS, Sanchez OA. Response of blood lipids to exercise training alone or combined with dietary intervention. Med Sci Sports Exerc. 2001;33:S502-S515.

22. Rashidlamir A, Ghanbariniaki A. Effect of a 6-week wrestling and wrestling-technique based circuit exercise on plasma lipoprotein profiles and hormone levels in well-trained wrestlers. International Journal of Wrestling Science. 2011;1:55-61.

23. Imamoglu O. Acute effect of aerobic and anaerobic exercise on lipid levels. Health Med. 2014;8:112-118.

24. Lemieux I, Lamarche B, Couillard C, Pascot A, Cantin B, Bergeron J, Després JP. Total cholesterol/HDL cholesterol ratio vs LDL cholesterol/ HDL cholesterol ratio as indices of ischemic heart disease risk in men: the Quebec Cardiovascular Study. Arch Intern Med. 2001;161:26852692.

25. Rosato FD. Fitness and Wellness: the Physical Connection. St. Paul; West Publishing Company; 1990:24-48.

26. Mann S, Beedie C, Jimenez A. Differential effects of aerobic exercise, resistance training and combined exercise modalities on cholesterol and the lipid profile: review, synthesis and recommendations. Sports Med. 2014; 44:211-221.

27. Tambalis K, Panagiotakos DB, Kavouras SA, Sidossis LS. Responses of blood lipids to aerobic, resistance, and combined aerobic with resistance exercise training: a systematic review of current evidence. Angiology. 2008;60:614-632. 